\title{
Getting started: altering promoter choice as a mechanism for cell type differentiation
}

\author{
Mukulika Ray and Erica Larschan \\ Department of Molecular Biology, Cellular Biology, and Biochemistry, Brown University, Providence, Rhode Island 02912, USA
}

In this issue of Genes \& Development, Lu and colleagues (pp. 663-677) have discovered a key new mechanism of alternative promoter choice that is involved in differentiation of spermatocytes. Promoter choice has strong potential as mechanism for differentiation of many different cell types.

Cell differentiation is both a fascinating and intriguing aspect of the development of multicellular organisms. Regulated gene expression plays a pivotal role in determining the spatial and temporal direction of cellular maturity and diversity (Arney and Fisher 2004). Gene expression during differentiation involves tightly regulated interactions between specific DNA regulatory sequences and protein complexes that can specifically bind to them. Much emphasis has been placed on the role of distal enhancer elements in shaping tissue type-specific transcription at core promoters (Haberle and Stark 2018). For example, certain promoter-proximal elements affect the activities of both enhancers and promoters, which is essential for regulating the specificity of their interactions (Calhoun et al. 2002; Andersson and Sandelin 2020).

However, we are realizing the important role of specific promoter-proximal motifs in directly influencing transcription of genes activated during the differentiation from one cell type to another. For example, protein complexes such as tMAC and dREAM cause either activation or repression of different promoters depending on composition of the complex specific for a particular cell type/ stage (Beall et al. 2007; Sadasivam and DeCaprio 2013; Lu and Fuller 2015; Laktionov et al. 2018; Andersson and Sandelin 2020). However, the mechanism by which this choice occurs remained unknown.

Here, Lu et al. (2020) have shown that these complexes can make use of alternate promoters with unique proximal motifs bound by cell type-specific factors to turn off the ongoing transcriptional program and start a new program to transition between two different cell types. This

[Keywords: Drosophila; spermatogenesis; transcription; tMAC; core promoter elements]

Corresponding author: erica_larschan@brown.edu

Article is online at http://www.genesdev.org/cgi/doi/10.1101/gad.338723. 120 . is also a very efficient mechanism for assuring the same level of transcription of the same gene in two totally different cellular environments with variable protein composition. Previously, alternate promoters were reported as means of achieving mRNA heterogeneity in particular tissue types (Landry et al. 2003; Zhang et al. 2007). The present study reveals how the tMAC complex can act similarly to a pioneer factor to initiate transcription by opening cell type-specific promoters by remodeling the nucleosomes present there.

Furthermore, some tMAC components have features found in known pioneer factors such as HNF3 /Cirillo et al. 1998; White-Cooper 2010). Also, there are reports showing dREAM, a similar complex, can recruit other remodeling proteins that in turn can loosen chromatin and thus open chromatin at target loci (Mages et al. 2017). At present, this is a possible mechanistic model that needs to be tested by further biochemical analysis. The presence of other factors that can limit the activity and spread of tMAC complex-induced transcription at multiple promoters indicates the presence of a multilayered fine-tuned regulation essential for such highly dynamic and intricate mechanisms of cell differentiation.

Moreover, tMAC is highly conserved across species, and there are many other protein complexes present that show tissue- or stage-specific binding to chromatin in all phyla (Kent et al. 2004; Creppe et al. 2014; Gregory 2018). Also, the presence of alternate promoters is long known across all organisms to increase tissue transcriptome diversity. There are reports describing several motifs present in promoters that have undefined functions (Smith et al. 2006; Down et al. 2007). Therefore, it is very likely that interplay between chromatin-binding protein complexes and promoter-proximal motifs regulating terminal cell differentiation in different organs will prove to be a highly conserved process in diverse organisms. 


\section{Acknowledgments}

M.R. acknowledges her father, who was the first person to introduce her to the world of scientific thinking and the living kingdom. He inspired her to be inquisitive about her surroundings and be a problem solver.

\section{References}

Andersson R, Sandelin A. 2020. Determinants of enhancer and promoter activities of regulatory elements. Nat Rev Genet 21: 71-87. doi:10.1038/s41576-019-0173-8

Arney KL, Fisher AG. 2004. Epigenetic aspects of differentiation. J Cell Sci 117: 4355-4363. doi:10.1242/jcs.01390

Beall EL, Lewis PW, Bell M, Rocha M, Jones DL, Botchan MR. 2007. Discovery of tMAC: a Drosophila testis-specific meiotic arrest complex paralogous to Myb-Muv B. Genes Dev 21:904919. doi:10.1101/gad.1516607

Calhoun VC, Stathopoulos A, Levine M. 2002. Promoter-proximal tethering elements regulate enhancer-promoter specificity in the Drosophila antennapedia complex. Proc Natl Acad Sci 99: 9243-9247. doi:10.1073/pnas.142291299

Cirillo LA, McPherson CE, Bossard P, Stevens K, Cherian S, Shim EY, Clark KL, Burley SK, Zaret KS. 1998. Binding of the winged-helix transcription factor HNF3 to a linker histone site on the nucleosome. EMBO I 17: 244-254. doi:10.1093/ emboj/17.1.244

Creppe C, Palau A, Malinverni R, Valero V, Buschbeck M. 2014. A Cbx8-containing polycomb complex facilitates the transition to gene activation during ES cell differentiation. PLoS Genet 10: e1004851. doi:10.1371/journal.pgen.1004851

Down TA, Bergman CM, Su J, Hubbard TJ. 2007. Large-scale discovery of promoter motifs in Drosophila melanogaster. PLoS Comput Biol 3: e7. doi:10.1371/journal.pcbi.0030007

Gregory BD. 2018. Shedding some blue light on alternative promoter usage in plants. Proc Natl Acad Sci 115: 7654-7656. doi:10.1073/pnas.1809312115

Haberle V, Stark A. 2018. Eukaryotic core promoters and the functional basis of transcription initiation. Nat Rev Mol Cell Biol 19: 621-637. doi:10.1038/s41580-018-0028-8
Kent NA, Eibert SM, Mellor J. 2004. Cbf1p is required for chromatin remodeling at promoter-proximal CACGTG motifs in yeast. I Biol Chem 279: 27116-27123. doi:10.1074/jbc .M403818200

Laktionov PP, Maksimov DA, Romanov SE, Antoshina PA, Posukh OV, White-Cooper H, Koryakov DE, Belyakin SN. 2018. Genome-wide analysis of gene regulation mechanisms during Drosophila spermatogenesis. Epigenetics Chromatin 11: 14. doi:10.1186/s13072-018-0183-3

Landry JR, Mager DL, Wilhelm BT. 2003. Complex controls: the role of alternative promoters in mammalian genomes. Trends Genet 19: 640-648. doi:10.1016/j.tig.2003.09.014

Lu C, Fuller MT. 2015. Recruitment of Mediator complex by cell type and stage-specific factors required for tissue-specific TAF dependent gene activation in an adult stem cell lineage. PLOS Genet 11: e1005701. doi:10.1371/journal.pgen.1005701

Lu D, Sin H-S, Lu C, Fuller MT. 2020. Developmental regulation of cell type-specific transcription by novel promoter-proximal sequence elements. Genes Dev (this issue). doi:10.1101/gad .335331 .119

Mages CF, Wintsche A, Bernhart SH, Müller GA. 2017. The DREAM complex through its subunit Lin37 cooperates with $\mathrm{Rb}$ to initiate quiescence. Elife 6: e26876. doi:10.7554/eLife .26876

Sadasivam S, DeCaprio JA. 2013. The DREAM complex: master coordinator of cell cycle-dependent gene expression. Nat Rev Cancer 13: 585-595. doi:10.1038/nrc3556

Smith AD, Sumazin P, Xuan Z, Zhang MQ. 2006. DNA motifs in human and mouse proximal promoters predict tissue-specific expression. Proc Natl Acad Sci 103: 6275-6280. doi:10.1073/ pnas.0508169103

White-Cooper H. 2010. Molecular mechanisms of gene regulation during Drosophila spermatogenesis. Reproduction 139: 11-21. doi:10.1530/REP-09-0083

Zhang SX, Searcy TR, Wu Y, Gozal D, Wang Y. 2007. Alternative promoter usage and alternative splicing contribute to mRNA heterogeneity of mouse monocarboxylate transporter 2. Physiol Genomics 32: 95-104. doi:10.1152/physiolgenomics .00192 .2007 


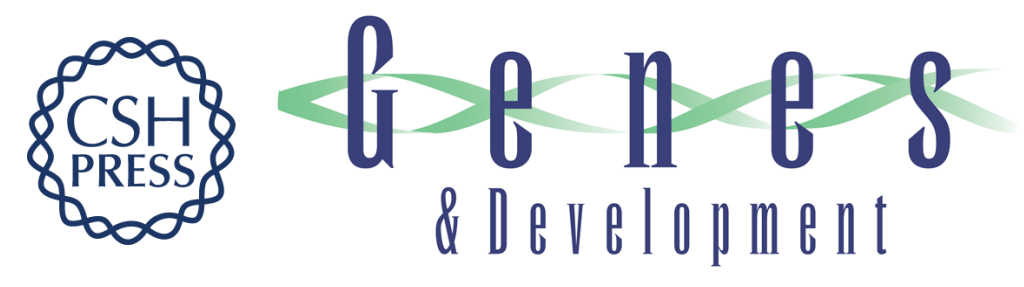

\section{Getting started: altering promoter choice as a mechanism for cell type differentiation}

Mukulika Ray and Erica Larschan

Genes Dev. 2020, 34:

Access the most recent version at doi:10.1101/gad.338723.120
Related Content Developmental regulation of cell type-specific transcription by novel promoter-proximal sequence elements Dan Lu, Ho-Su Sin, Chenggang Lu, et al. Genes Dev. May , 2020 34: 663-677

References This article cites 19 articles, 8 of which can be accessed free at: http://genesdev.cshlp.org/content/34/9-10/619.full.html\#ref-list-1

Articles cited in: http://genesdev.cshlp.org/content/34/9-10/619.full.html\#related-urls

Creative This article is distributed exclusively by Cold Spring Harbor Laboratory Press for the first Commons License six months after the full-issue publication date (see http://genesdev.cshlp.org/site/misc/terms.xhtml). After six months, it is available under a Creative Commons License (Attribution-NonCommercial 4.0 International), as described at http://creativecommons.org/licenses/by-nc/4.0/.

Email Alerting Receive free email alerts when new articles cite this article - sign up in the box at the top right corner of the article or click here.

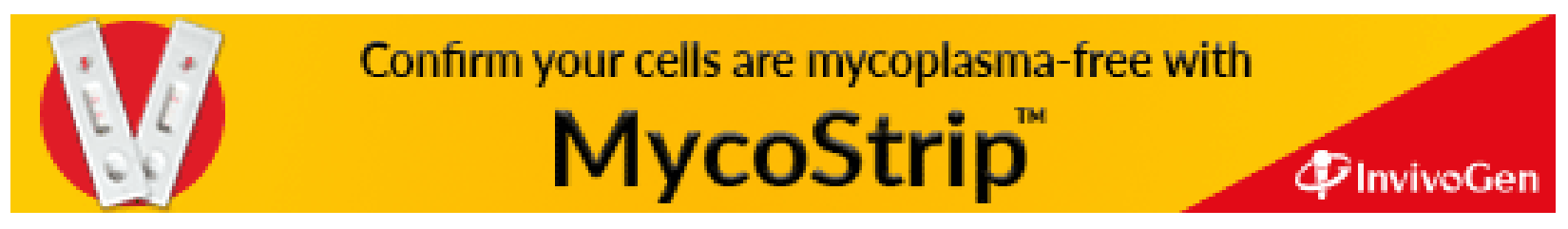

